\title{
Social media, learning and connections for international students: The disconnect between what students use and the tools learning management systems offer
}

\author{
Jade Sleeman, Catherine Lang, Eva Dakich \\ La Trobe University
}

\begin{abstract}
With the increased focus on the use of digital platforms to facilitate teaching and learning comes the challenge of creating connections between international students and their new classmates. The use of social media in higher education may be one avenue that can enable not only learning but also social connections between students to improve the international study experience and sense of community. This article reports on the findings of a small survey study at an Australian university, which demonstrate that the majority of international students surveyed had greater prior experience with social network sites for personal and educational use rather than wikis, blogs, and discussion forums, which are often used in institutional settings. Furthermore, the results suggest that the educational use of social network sites led many participants to add new classmates as profile friends. These findings have implications for the choice of digital platforms for pedagogical use of social media and how that may impact on the teaching of international students in higher education for making connections.
\end{abstract}

Implications for practice or policy:

- Educators can use social media in the classroom to increase opportunities for international students to make digital connections with peers.

- Institutional social media policies need to provide more clarity around educators' responsibilities when using social network sites in the classroom.

- Higher education institutions need to consider designing digital learning platforms that incorporate social network site capabilities.

Keywords: international students, higher education, social media, social network sites, learning management systems

\section{Introduction}

Studying at a university in a foreign country can be an opportunity to expand educational and professional horizons, while also engaging with diverse cultural and social circles (Marginson, 2009). Yet, international students often face the difficulties of acculturation and adjustment because of stress, anxiety, and loneliness (Anderson, Carmichael, Harper, \& Huang, 2010). Thus, finding ways to connect international students with their new peers can ease academic and social adjustment (Hendrickson, Rosen, \& Aune, 2011), and consequently facilitate improved learning outcomes (Tinto, 1997; C.-M. Zhao \& Kuh, 2004).

With the use of digital technologies increasing in higher educational institutions to engage students in learning contexts beyond the classroom, it becomes more necessary to harness the affordances of social media tools for student interaction $(\mathrm{Ng}, 2015)$. Most universities now offer students learning experiences mediated by an institutional online learning management system (LMS), such as Moodle or Blackboard, which includes various social media tools, like wikis, blogs, and discussion forums (Consoli, 2013). The term social media generally refers to "a group of internet-based applications ... that allow the creation and exchange of User Generated Content" (Kaplan \& Haenlein, 2010, p. 61). Among an ever-expanding list of applications, social media can include wikis, blogs, discussion forums, virtual worlds, content communities, and online gaming. Educators have employed many of these online platforms to facilitate teaching and learning according to the unique affordances each platform offers and the ways in which users can interact (Joosten, 2012). Kaplan and Haenlein (2010) highlighted the differences between these various social media in terms of the degree of social presence and media richness, and self-presentation and self-disclosure that the application offers. In particular, a social network site (SNS) as a "networked communication platform" (Ellison \& boyd, 2013, p. 158), where users are able to engage with each other through publicly 
connected profiles, can be higher in social presence and media richness, and self-presentation and selfdisclosure than the formal applications generally offered by higher education institutions, such as wikis, blogs, and discussion forums (Kaplan \& Haenlein, 2010).

Due to the socio-technological affordances of these applications, SNSs have now become a legitimate locus for social connection for many people (Ledbetter, 2016). As such, this social aspect of SNS usage can also be pertinent in educational circumstances (Deepak, Wisner, \& Benton, 2016). The incorporation of SNSs into learning activities may be one avenue for providing international students with extended forms of social interaction, which can have a positive impact on their experience of studying overseas (Hendrickson et al., 2011). The survey study presented in this article focused on determining how international students used social media and how this use impacted on their perceptions of social connectedness for learning. Data was collected from international students at an Australian university about their personal uses of social media and educational experiences of making digital connections with classmates.

\section{Review of current research}

\section{Use of social media in higher education}

Social media technologies, or "virtual spaces where people share" (Joosten, 2012, p. 6), have become ubiquitous in both personal and professional contexts. These online spaces that enable "interactivity, participation, collaboration, and the dispersal of expertise and intelligence" (Lankshear \& Knobel, 2011, p. 76) are now also increasingly used in higher education to engage students in learning in new ways (Balkin \& Sonnevend, 2016; Dede, 2016). In the educational employment of these technologies, the affordances have generated not only optimism about the new possibilities to blur boundaries between formal and informal learning spaces (Greenhow \& Lewin, 2016) but also concern for the complexities created by "collapsing contexts" (Marwick \& boyd, 2011) between personal and academic lives (Selwyn \& Stirling, 2016; Sleigh, Smith, \& Laboe, 2013). This opens up unexplored communication protocols and standards between students and academics in light of online viral movements, such as \#metoo in 2017 (Zarkov \& Davis, 2018). In this constantly evolving online landscape, higher education institutions have found it difficult to respond with adequate policies that govern the use of social media for professional purposes (Pomerantz, Hank, \& Sugimoto, 2015). Furthermore, many educators are struggling to adapt to facilitating learning in online spaces, due to factors such as a lack of understanding of the potential of using social media tools to create interactive learning environments (Ajjan \& Hartshorne, 2008), unfamiliarity with new digital technologies (Manca \& Ranieri, 2016b), or a lack of training (Manca \& Ranieri, 2017).

Promoted for their interactive and collaborative potential, online technologies such as wikis, blogs, discussion forums, and SNSs have been seen to align with constructivist pedagogies (Kimmerle, Moskaliuk, Oeberst, \& Cress, 2015). As such, educational research has focused on the different types of social media technologies and their various affordances to enact social learning contexts (Poore, 2013). For example, wikis have been employed by educators to facilitate peer scaffolding and feedback in collaborative writing tasks (Athanassios \& Dimitrios, 2017; Moskaliuk, Kimmerle, \& Cress, 2012). Blogs have also been used to engage students in reflective learning and knowledge sharing (Chawinga, 2017; Jackling, Natoli, Siddique, \& Sciulli, 2015; Laru, Näykki, \& Järvelä, 2012). In addition, dialogic interaction between students, and also with teachers, can be stimulated through the use of online discussion forums (Kear, Woodthorpe, Robertson, \& Hutchison, 2010; P.-Y. Wang \& Yang, 2012). More recently, SNSs have also been subsumed into higher education teaching to connect students for learning interactions through applications such as Twitter and Facebook (Bal, Grewal, Mills, \& Ottley, 2015; Cooke, 2015; McCarthy, 2013).

In discussing the various affordances of social media for educational purposes, it should be noted that the research does not always support the establishment of productive learning environments through the use of these applications (Piotrowskj, 2015; Selwyn \& Stirling, 2016); nor is there always a willingness for educators to use these technologies (Manca \& Ranieri, 2016a). Applications such as wikis, blogs; and discussion forums are often included in the institutional provisions of higher education systems used to facilitate online or blended learning, such as an LMS. However, the affordances of these formal systems do not always facilitate student interaction in online spaces (Barczyk \& Duncan, 2013; Deng \& Tavares, 2015). This may be due to the lack of social presence afforded by the LMS technology (Brady, Holcomb, \& Smith, 2010; Minocha, 2009). For example, Kaplan and Haenlein (2010) categorised blogs as high in 
self-presentation and self-disclosure, though low in social presence and media richness, while wikis are classified as low in both dimensions. In comparison to these social media tools offered in an LMS, SNSs enable users more capacity for communication between individuals in association with content sharing and relationship building (Barczyk \& Duncan, 2012). Yet, the use of SNSs can also be problematic in a learning environment if the technological facilities of the platform do not lend themselves well to the task (Osgerby \& Rush, 2015; Owens \& Nussbaum, 2016), lead to distractions for students (Flanigan \& Babchuk, 2015; Selwyn, 2016), or create tensions for educators in maintaining professional identities through the blurring of personal and academic online spaces (Raynes-Goldie \& Lloyd, 2014; Veletsianos \& Kimmons, 2013). Further studies of SNSs as platforms for students to engage in educational interactions have suggested that while some students and teachers may not be comfortable mixing the educational use of these platforms in their personal lives, the affordances of social presence on SNSs increase the likelihood of social learning interactions taking place between students (Cuesta, Eklund, Rydin, \& Witt, 2016; Gettman \& Cortijo, 2015; Tess, 2013). Therefore, in negotiating these tensions, research has also investigated the capacity to use social networking technologies as an LMS that replicates an SNS platform within a closed network, such as alternative commercial applications such as Elgg (Veletsianos, Kimmons, \& French, 2013) or Ning (Brady et al., 2010). In these applications, staff and students are able to interact in ways similar to a platform such as Facebook, without intruding into personal communication spaces.

Of the many social media applications discussed, SNSs have the capacity to facilitate social connections through online social presence in ways that may enhance feelings of connectedness with others (Grieve, Indian, Witteveen, Tolan, \& Marrington, 2013). As shown in educational research, social connectedness has benefits not only for cognitive capacity but also for student engagement, which is a positive predictor of academic success (Tinto, 1997; C.-M. Zhao \& Kuh, 2004). With educational research also increasingly identifying frameworks for the design of tasks involving social media technologies in ways that promote active and collaborative learning (Bower, Hedberg, \& Kuswara, 2010; Doyle, Sammon, \& Neville, 2015; Kimmerle et al., 2015), productive use of social networking technologies for online learning activities may have the added benefit of increasing feelings of social connectedness to classmates (Deepak et al., 2016).

\section{International students and social media use}

At the same time that many universities are transitioning to more digitally mediated pedagogies, changes in the makeup of the student body are also occurring. In Australia in 2015, around 260,000 international students accounted for approximately $20 \%$ of the tertiary student cohort (Australian Government, 2016). This trend was echoed in other top destination countries for overseas students, where in 2016 almost 435,000 international students made up roughly $20 \%$ of university enrolments in the United Kingdom (Higher Education Statistics Agency, 2017), and though only 5\% of higher education enrolments, over 1 million overseas students studied in the United States of America between 2015 and 2016 (Institute of International Education, 2017).

Studies of educational uses of social media and international students have examined the challenges and affordances of these platforms for learning purposes. These studies have reported that engaging in online communication can pose problems for international students with language difficulties (Habib, Johannesen, \& Leikny, 2014; Thompson \& Ku, 2005; C. M. Wang \& Reeves, 2007) or differences in cultural understandings (Liu, Liu, Lee, \& Magjuka, 2010; Zhang \& Kenny, 2010; N. Zhao \& McDougall, 2008). The advantages of using social media for learning have also been documented, with international students reporting having more time to compose and understand communication in asynchronous online environments (Dillon, Wang, \& Tearle, 2007; Erichsen \& Bolliger, 2011), as well as having greater confidence in sharing opinions (Thompson \& Ku, 2005; N. Zhao \& McDougall, 2008).

Though international students may face a variety of challenges adjusting to a new cultural and educational context (Anderson et al., 2010), social connection is one aspect that can improve this transition (Hendrickson et al., 2011). Thus, research on international students and social media has also focused on students' personal uses of applications for social connection. In this capacity, studies of international students' use of social media have highlighted how digital platforms can be used to mediate adjustment to the new educational and living context (Forbush \& Foucault-Welles, 2016; Mikal, Yang, \& Lewis, 2015; Rui \& Wang, 2015). This type of research generally has focused on concerns for social connectedness and how foreign students build bridging capital in online spaces through their personal use of social media. For example, the use of social media, such as SNSs, blogs, and discussion forums, can play a critical role during 
an overseas study experience in enabling a continuity of home culture interactions, which can increase social and academic adjustment for international students (Forbush \& Foucault-Welles, 2016; Mikal et al., 2015; Shao \& Crook, 2015). Research, however, has suggested that the particular use of SNSs for developing host country bonds can assist greater adjustment to the new educational and cultural context (Lin, Peng, Kim, Kim, \& LaRose, 2012; Park, Song, \& Lee, 2014; Rui \& Wang, 2015). It has been noted that a variety of SNSs exists and there may be cultural differences in the use of preferred online platforms (Hargittai, 2007), especially for students from Asia preferring home country sites, such as WeChat or Renren (Gomes, Berry, Alzougool, \& Chang, 2014; Park et al., 2014; Tian, 2015). As such, research has suggested that exclusive use of home country SNSs may exclude opportunities to interact with individuals from the host culture who are using alternative digital platforms (Li \& Chen, 2014; Park et al., 2014). For this reason, there may be benefits for international students to use the popular SNSs of the country in which they are studying (Lee \& Ranta, 2014; Park et al., 2014). However, the research has also suggested that simply using the popular host country SNSs, such as Facebook, does not necessarily lead to students connecting with host country social networks (Lee \& Ranta, 2014).

While the literature indicates that international students experience both the aforementioned benefits and challenges associated with social media use in educational and personal capacities, there seems to be a lack of investigation of the intersection between these spheres (Sleeman, Lang, \& Lemon, 2016). Furthermore, investigations of international students' educational uses of social media have placed limited focus on its personal impact on the lives of students. Though research on social media has noted pedagogical affordances for active and collaborative learning (Kimmerle et al., 2015), it is important to consider the affective dimension of communicating and relationship building with social networking (Bosman \& Zagenczyk, 2011). Therefore, the use of social media, and SNSs specifically, for educational activities may contribute to positive outcomes for international students not only academically but also personally (McCarthy, 2013). As a result of the gap in investigating how the educational use of social media impacts on social connections for international students, this study examined the following questions:

(1) How do international students use social media for personal and educational purposes?

(2) How do educational uses of social media impact on international students' perception of social connectedness?

\section{Methods}

\section{Participants and the research setting}

The participants in this study were international students from language backgrounds other than English, recruited prior to their commencement in degree courses at a metropolitan university in Melbourne, Australia. The investigation was granted human ethics approval and involved volunteer sampling of students completing academic English preparation courses at the university. This resulted in 43 participants completing an online survey in a link that was emailed to students, regarding their uses of social media for both personal and educational purposes. Participants completed the online survey prior to starting their degree course in either semester 1 or semester 2 in the Australian academic year of 2016.

The final participant sample consisted of 21 males and 22 females, with 30 under the age of 25, eight aged 26-30, three aged 31-35, and two aged 36-40. Of these participants, 21 were about to commence an undergraduate degree and 22 were starting a postgraduate degree. From the respondent sample, the three major Australian international student source countries (Australian Government, 2016) were represented with 11 students from China, 11 students from India and eight students from Vietnam. The remaining participants were from Indonesia, Thailand, Nepal, Sri Lanka, Russia, Argentina, Oman, Saudi Arabia, Iran, and Iraq.

\section{Data collection and analysis}

As a survey study, this research aimed to explore a specific phenomenon with a particular group to enable "generalizations about an instance" (Cohen, Manion, \& Morrison, 2011, p. 256). The online survey instrument was developed using Qualtrics software and consisted of 22 items of closed, multiple-choice, and short-answer questions on participants' demographics, activities, and platforms using social media technologies, and the use of social media for learning. A Likert scale derived from Barczyk and Duncan 
(2013) was also used to collect information about their perceptions of social connectedness using social media for learning.

The data generated from the survey was then analysed in Qualtrics reports using descriptive statistics to illuminate variables in the participant group. Though the survey sample was too small to provide statistically significant results, this approach was used as a method for gathering participant details, to provide a snapshot of their experiences of social media use prior to their commencement of degree courses at an Australian university and to gain an understanding of their perceptions regarding online social connectedness for learning.

\section{Findings}

\section{How do international students use social media for personal and educational purposes?}

The international students in this study used various types of social media, but they tended to be more active in their use of SNSs than other types of platforms. In addition, although Facebook was a popularly used SNS, there were differences in the platforms that students used, especially for students from China, who often preferred to use a Chinese language application. However, many students from China had begun using Facebook to connect with classmates since arriving in Australia.

The data collected demonstrated that of 43 participants, 35 used an SNS at least daily or weekly, with only one participant who did not use SNSs at all (see Table 1). In comparison, active participation in other social media activities was less common. For example, fewer than half of the participants were sharing videos or photos daily or weekly on sites such as YouTube or Flickr. This indicates that many were more comfortable being consumers of information on these sites, rather than creators. This is verified by the findings that regular commenting on other people's blogs or vlogs was engaged in by only about $50 \%$ of the sample, while almost half of the sample had similarly never kept a blog or vlogs.

Table 1

Participants' reported frequency of use of social media technologies $(n=43)$

\begin{tabular}{llllll}
\hline & Daily & Weekly & Monthly & $>$ Monthly & Never \\
\hline Use SNSs & $81 \%$ & $14 \%$ & 0 & $2 \%$ & $2 \%$ \\
Share on photo and/or video sites & $7 \%$ & $37 \%$ & $14 \%$ & $16 \%$ & $25 \%$ \\
Keep own blog & $9 \%$ & $23 \%$ & $9 \%$ & $14 \%$ & $44 \%$ \\
Read blogs & $30 \%$ & $30 \%$ & $18 \%$ & $11 \%$ & $9 \%$ \\
Comment on blogs & $23 \%$ & $25 \%$ & $9 \%$ & $23 \%$ & $18 \%$ \\
\hline
\end{tabular}

In terms of the SNSs that participants were using, Facebook was the most popular with 41 respondents. The second most popular sites were Instagram $(n=24)$, Google $+(n=15)$, and Twitter $(n=14)$. For students from China, Chinese language SNSs such as WeChat $(n=11)$ and Weibo $(n=9)$ were also popular. LinkedIn was also a popular SNS with Indian postgraduate students $(n=7)$, which may reflect a strong interest in job opportunities. A majority of Indian and Chinese students used Instagram, with eight and seven respondents respectively. Seven of the Indian students also used Twitter, compared to only four Chinese students. Only three Vietnamese students used Instagram, and none used Twitter.

While this data suggests that Facebook was the most popular SNS among a variety used by students in this study, it was not necessarily a site that all students preferred. Facebook was a preferred application for almost $60 \%$ of students from a range of countries, including India, Vietnam, Iraq, Iran, Indonesia, Russia, and Argentina. In contrast, most of the Chinese students preferred a Chinese language platform, with eight out of 11 Chinese participants listing either WeChat or Weibo as their favoured SNS.

Despite having preferred social media platforms, some participants had begun to use new SNSs since arriving in Australia. Of the 43 respondents to the survey, 22 had begun using a new SNS since arriving in Australia, with the largest number starting to use Facebook $(n=12)$, followed by WeChat $(n=5)$, and Instagram $(n=4)$. The students beginning to use Facebook were mostly Chinese $(n=9)$, followed by one student each from Oman, Saudi Arabia, and India. For the participants beginning to use WeChat, nationalities included China, Oman, Saudi Arabia, India, and Argentina. Three students from China had also started using Instagram, and two had started using Twitter. One Chinese student also listed Weibo and 
Renren as new SNSs used since arriving in Australia. A range of other sites were also cited, such as LinkedIn, an employment-based SNS, and Badoo and Tinder, both friendship or dating SNSs.

For students new to using Facebook, the reasons related to having contact with others who were using Facebook. For example, students cited "classmates", "other students", and "friends" using Facebook. One Chinese student noted Facebook's "international" character, two others listed "international friends" and "international students" as users. In addition, two Chinese students listed having contact with local users as Facebook is "most commonly used by australias (sic)" and "most of local friends use that (sic)".

With the majority of participants using SNSs regularly in their personal lives, they were also asked to elaborate on the kinds of engagement they took part in on these sites. Compared to the number of students using social media to actively participate through the creation of information, for example, sharing of videos or photos, keeping a blog, or commenting on other people's blogs, participants were more likely to be active users of SNSs. For example, almost $60 \%$ shared or posted up to once a week, while over $70 \%$ of students liked or commented on other people's posts on an SNS at least once a week (see Table 2).

Table 2

Participants' reported frequency of SNS use $(n=40)$

\begin{tabular}{llllll}
\hline & Daily & $\begin{array}{l}\mathbf{2 - 3} \text { times a } \\
\text { week }\end{array}$ & Once a week & $\begin{array}{l}\mathbf{2 - 3} \text { times a } \\
\text { month }\end{array}$ & $\begin{array}{l}\text { Once a } \\
\text { month or less }\end{array}$ \\
\hline Visit site & $87.5 \%$ & $12.5 \%$ & $0 \%$ & $0 \%$ & $0 \%$ \\
Like or favourite & $55 \%$ & $17.5 \%$ & $10 \%$ & $7.5 \%$ & $10 \%$ \\
Comment & $32.5 \%$ & $30 \%$ & $15 \%$ & $5 \%$ & $17.5 \%$ \\
Share or post & $20 \%$ & $27.5 \%$ & $15 \%$ & $10 \%$ & $27.5 \%$ \\
\hline
\end{tabular}

Overall, the international students in this study used social media regularly and were more active in their use of SNSs than other content-sharing applications, such as blogs, which are often incorporated in a course LMS. While Facebook was an almost universally used platform, students from China preferred Chinese language applications, such as WeChat or Weibo. Despite this preference, many students from China had also started using Facebook to connect with classmates.

The international students in this study also had experienced using various types of social media for learning, both in their home countries and in Australia. In these prior experiences, the use of SNSs was more prevalent than the applications that are often provided by higher education institutions, such as wikis, blogs, and forums. Many of the participants had added classmates as friends through the use of SNSs for learning activities in their studies in Australia and generally had positive views of social media use for facilitating a sense of online connectedness.

Over $80 \%$ of the sample $(n=36)$ had some experience with the educational use of social media technologies prior to their arrival in Australia. The most commonly used social media for study in the home country were SNSs, with 25 respondents. This was followed by video and photo sharing sites with 22 respondents. Of the respondents, 18 had also used wikis for learning activities, while only nine had used discussion forums and eight had used blogs. Seven participants had not had any experience using social media applications for learning prior to coming to Australia.

In terms of differences amongst participants representing the three largest nationalities in the participant group, China, India, and Vietnam, it seems that students from China had comparatively less experience of using discussion forums for learning in their home country, with only one respondent. In comparison, three students from India had used discussion forums for study purposes and four students from Vietnam. On the other hand, a higher proportion of students from India (72\%) reported using wikis for learning than students from China (36\%) and Vietnam (37\%).

In Australia, during their education at the university's English language centre, the participants had more experience of educational social media use, with 41 respondents, or $95 \%$, having used a social media technology for learning. The use of SNSs was again the most common social media for learning, with 32 respondents, and video and photo sharing sites had been used by 22 participants. There was less experience of wiki use at the language centre, with 15 respondents, compared to 18 respondents using them in their home countries. Fewer participants had experienced using blogs for learning at the language centre, with 
only five respondents, though there was slightly more use of discussion forums with seven respondents. Only two participants had not experienced using any type of social media for learning during their English language studies at the university.

\section{How do educational uses of social media impact on international students' perception of social connectedness?}

Participants who had used social media for educational activities in their English language studies in Australia were also asked about their connections to classmates. Of the 32 participants who had used SNSs for study at the language centre, 26 added classmates as friends to their profile after using the platforms for educational activities, while six did not add any friends. The number of classmates that participants added as friends to their SNS profile ranged, with 10 participants adding fewer than 10 friends, eight participants adding more than 10, two adding more than 20, and five students adding more than 30 classmates as SNS friends. In the group of students who had used SNSs for learning at the language centre but had not added any friends to their profile, Vietnamese students were represented with three students, while one student each from China, Oman, and Iraq were also represented.

The international students in this study generally rated their perceptions of online social connectedness for learning favourably. Of the participant sample, almost 75\% agreed that "social media allow me to share my personal interests with classmates", "social media allow me to find and share educational resources", and "social media promote knowledge sharing" (see Table 3). Over $80 \%$ of participants either agreed $(n=32)$ or strongly agreed $(n=2)$ that "social media allow me to discuss topics of interest". The final two items had the most agreement, with almost all participants agreeing that "social media allow me to communicate with classmates" ( $n=26$ agree and $n=14$ strongly agree). Finally, $85 \%$ of participants agreed that "social media provide opportunities to work together with other students" ( $n=28$ agree and $n=7$ strongly agree).

Table 3

Participants' reported perceptions of connectedness using social media for learning $(n=41)$

\begin{tabular}{|c|c|c|c|c|c|}
\hline Social media ... & $\begin{array}{l}\text { Strongly } \\
\text { disagree }\end{array}$ & Disagree & $\begin{array}{l}\text { Neither agree } \\
\text { nor disagree }\end{array}$ & Agree & $\begin{array}{l}\text { Strongly } \\
\text { agree }\end{array}$ \\
\hline $\begin{array}{l}\text {... allow me to share my } \\
\text { personal interests with } \\
\text { classmates. }\end{array}$ & $3 \%$ & $7 \%$ & $12 \%$ & $68 \%$ & $10 \%$ \\
\hline $\begin{array}{l}\ldots \text { allow me to find and share } \\
\text { educational resources. }\end{array}$ & $5 \%$ & $0 \%$ & $17 \%$ & $68 \%$ & $10 \%$ \\
\hline ... promote knowledge sharing. & $3 \%$ & $0 \%$ & $17 \%$ & $68 \%$ & $12 \%$ \\
\hline $\begin{array}{l}\ldots \text { allow me to discuss topics of } \\
\text { interest. } \\
\ldots \text { allow me to communicate }\end{array}$ & $0 \%$ & $7 \%$ & $10 \%$ & $78 \%$ & $5 \%$ \\
\hline $\begin{array}{l}\text { with classmates. } \\
\text {.. provide opportunities to }\end{array}$ & $0 \%$ & $0 \%$ & $3 \%$ & $63 \%$ & $34 \%$ \\
\hline $\begin{array}{l}\text { work together with other } \\
\text { students. }\end{array}$ & $0 \%$ & $3 \%$ & $12 \%$ & $68 \%$ & $17 \%$ \\
\hline
\end{tabular}

Educational use of social media impacted on the perception of social connectedness of the international students in this study through their use of SNSs with classmates. The majority of participants added classmates as friends to their SNS profiles through the use of these sites for learning. In addition, their predominant prior experience of SNSs for learning was perceived to facilitate online social connectedness with classmates through knowledge sharing and communication.

\section{Discussion}

As the data in this research suggests, the use of social media in education can positively impact on the connections that international students make in a new host country. This confirms previous studies focusing on the use of digital platforms for interacting with new social networks while students are studying overseas (Forbush \& Foucault-Welles, 2016; Lin et al., 2012; Park et al., 2014; Rui \& Wang, 2015), though not in the context of educational use of these sites. While institutions often face difficulties in encouraging online student interaction through the use of official digital platforms, such as an LMS (Barczyk \& Duncan, 2013; 
Brady et al., 2010; Deng \& Tavares, 2015; Minocha, 2009), employing the social media tools that students themselves are familiar with may increase the likelihood of engagement and interaction with their peers. Thus, with the use of platforms such as Facebook, it is possible for students to make digital points of connection with classmates, which can then benefit engagement and academic outcomes.

While there is a plethora of social media technologies currently available, a notable finding from this study is that the platforms that international students are actively using are often not those that are frequently employed in university teaching contexts. This corroborates the findings of Deng and Tavares (2015) that international students are regular SNS users and are more active in their interactions with others on a personal communication platform than in using other content-sharing social media, such as blogs, which are often used within a course LMS. Furthermore, the international students in this study had little experience with blogs, forums, and wikis, compared to SNSs, which most had used for learning either in their home countries or in Australia.

Facebook was clearly a familiar platform for the students in this study and is often a site that has been popularly researched for use in educational contexts (Tess, 2013). Yet, Twitter, which has also gathered attention for its pedagogical potential (Chawinga, 2017; Cooke, 2015), was a site that few international students in this study were familiar with. As such, using a site like Facebook, which international students have more familiarity with, may garner more participation than using a site like Twitter, which students may have little experience using.

The findings in this study echo previous studies (Lee \& Ranta, 2014; Park et al., 2014), suggesting that even though international students may use different SNSs, arriving in the host country can also lead to the use of a different platform to connect with new friends and classmates. It is clear that some students had differences in the sites they preferred, which correlates with the research of different cultural preferences for SNS use (Hargittai, 2007). However, this does not necessarily impede students from starting to use other sites which they perceive can connect them with new peers. In this study, Facebook was the site that was clearly viewed for its international character to make connections with other students of different nationalities, especially for students from China.

A significant finding emerging from this study is the intersection between personal and educational contexts and how they may collide with the use of SNSs for educational purposes in a way that can help students make connections with peers. In this study, many international students who had used SNSs in learning contexts added classmates as friends to social media profiles and felt that social media facilitated connection through communication and sharing with classmates, which has also been found in other studies of students' educational use of SNSs (Barczyk \& Duncan, 2013; Deng \& Tavares, 2015; McCarthy, 2013). Thus, it is this personal potential of using SNSs for making connections with classmates through learning that can then have increased benefits for international students' academic adjustment and outcomes. However, this contrasts with research that has highlighted students and educators' concerns about distraction (Flanigan \& Babchuk, 2015; Selwyn, 2016) and the maintenance of privacy when using personal online spaces for educational purposes (Raynes-Goldie \& Lloyd, 2014). While the data eventuating from this study does not discount the possibilities of similarly negative attitudes to using personal social media platforms for learning, it does emphasise the benefits that may be lost by dismissing the use of these platforms altogether.

The findings of this research do not suggest that an institutional LMS does not have pedagogical merit for student interaction, but it does underscore the need for further investigation of the social implications of using SNS-type platforms in education. Universities have embraced the move to incorporating online spaces for teaching and learning, with both choices of institutional and open platforms having positives as well as attendant problems. This highlights the need for university social media policies to provide more clarity around educators' responsibilities when blurring the boundaries between professional and personal online spaces (Pomerantz et al., 2015), while also focusing efforts on developing educators' skills in using social media for pedagogical benefit (Manca \& Ranieri, 2017). Therefore, it is perhaps timely for institutions to direct efforts into developing institutional LMS platforms that support social networking software similar to SNSs, which can develop the online social presence of students in ways that promote connection, rather than the static broadcast systems that currently preside (Veletsianos et al., 2013). In this way, the boundaries between personal and educational online spaces can be preserved, while the affordances of social technologies can be leveraged for learning and connection. 


\section{Conclusion}

This study has highlighted how the educational use of digital platforms may have a personal impact on the international student experience. The international students in this study were active SNS users, with some opting to use new sites to interact with new friends in the host country. In addition, most students were familiar with using SNSs for learning rather than institutional platforms, such as LMSs, and found the benefit of adding classmates as friends on social network profiles through learning activities.

This article draws attention to the pedagogical opportunity for higher education institutions to design learning experiences that incorporate the advantages of using SNS capabilities to increase international students' engagement in learning and with their peers. Through the blurring of personal and academic online spaces, the educational use of SNSs may create opportunities for educators to engage international students in ways that benefit not only their academic learning but also their social adjustment. Familiarity through frequent use of these platforms for personal activity and the predominant experience of their use for learning purposes may make SNSs more suitable as online tools for academic purposes than those offered in an institutional LMS, such as blogs and forums. Furthermore, the use of SNSs by international students in educational contexts may allow for increased opportunities for making digital connections with peers.

However, this study shows a disconnect between the formal types of social media educators may use and the more informal social media that international students use. As the future of higher education increasingly moves to the facilitation of learning in online contexts, more research is needed on how the tools that educators use in digital spaces impact on the student experience of both learning and connection. It is true that research on educational adaptation of social media has tended to foreground the positive aspects of use, but there are, nevertheless, complexities that will still arise (Piotrowskj, 2015). One of these complexities is how educators can manage the affordances of a context collapse (Marwick \& boyd, 2011) where students and teachers can blend online academic discussions with personal interactions, without invading their private lives (Raynes-Goldie \& Lloyd, 2014). As such, there is perhaps the possibility for LMS platforms to incorporate technical interfaces that better mirror the online space of an SNS that students prefer to use in their personal lives, while also enabling a clear boundary to be maintained between students and teachers' academic lives.

\section{Future research and limitations}

By examining how international students negotiate personal and educational uses of social media for social connection during their time at a foreign university, a better understanding can be gained of how their experience of using social media for learning impacts on their social adjustment. Future studies that gather more qualitative data to explore students' experiences of using social media during their studies will enable a more thorough investigation that highlights the nuances of the international student experience in these online situations.

Additionally, further quantitative research that includes a larger sample size is needed to determine whether the implications of this study can be generalised to a wider population. This survey study was limited by the small number of participants, and as such, the findings may not be representative of a general international student population. Furthermore, the data was gathered at only one site, and thus the experiences of this cohort may be dependent on the similar variables that they shared. Future research would benefit from a cross-institutional analysis, as well as gathering data from a variety of international higher education contexts.

\section{References}

Ajjan, H., \& Hartshorne, R. (2008). Investigating faculty decisions to adopt Web 2.0 technologies: Theory and empirical tests. Internet and Higher Education, 11(2), 71-80. https://doi.org/10.1016/j.iheduc.2008.05.002

Anderson, G., Carmichael, K., Harper, T., \& Huang, T. (2010). International students at four-year institiutions. Developmental needs, issues and strategies In S. R. Harper \& S. J. Quaye (Eds.), Student 
engagement in higher education: Theoretical perspectives and practical approaches for diverse populations (1st ed., pp. 17-37). Hoboken, NJ: Taylor \& Francis.

Athanassios, J., \& Dimitrios, R. (2017). Students' collaborative patterns in a wiki-authoring project: Towards a theoretical and analysis framework. Journal of Applied Research in Higher Education, 9(1), 24-39. https://doi.org/10.1108/JARHE-05-2016-0034

Australian Government. (2016). Research snapshot: International student numbers 2015. Retrieved from https://internationaleducation.gov.au/research/ResearchSnapshots/Documents/Student $\% 20$ Numbers $\% 202015 . \mathrm{pdf}$

Bal, A. S., Grewal, D., Mills, A., \& Ottley, G. (2015). Engaging students with social media. Journal of Marketing Education, 37(3), 190-203. https://doi.org/10.1177/0273475315593380

Balkin, J., \& Sonnevend, J. (2016). The digital transformation of education. In C. Greenhow, J. Sonnevend, \& C. Agur (Eds.), Education and social media: Toward a digital future (pp. 9-24). Cambridge: MIT Press.

Barczyk, C. C., \& Duncan, D. G. (2012). Social networking media: An approach for the teaching of international business. Journal of Teaching in International Business, 23(2), 98-122. https://doi.org/10.1080/08975930.2012.718703

Barczyk, C. C., \& Duncan, D. G. (2013). Facebook in higher education courses: An analysis of students' attitudes, community of practice, and classroom community. International Business and Management, 6(1), 1-11. https://doi.org/10.3968/j.ibm.1923842820130601.1165

Bosman, L., \& Zagenczyk, T. (2011). Revitalize your teaching: Creative approaches to applying social media in the classroom. In B. White, I. King, \& P. Tsang (Eds.), Social media tools and platforms in learning environments (pp. 3-16). Heidelberg, Germany: Springer-Verlag.

Bower, M., Hedberg, J. G., \& Kuswara, A. (2010). A framework for Web 2.0 learning design. Educational Media International, 47(3), 177-198. https://doi.org/10.1080/09523987.2010.518811

Brady, K. P., Holcomb, L. B., \& Smith, B. V. (2010). the use of alternative social networking sites in higher educational settings: A case study of the e-learning benefits of Ning in education. Journal of Interactive Online Learning, 9(2), 151-170. Retrieved from http://www.ncolr.org/jiol/issues/pdf/9.2.4.pdf

Chawinga, W. D. (2017). Taking social media to a university classroom: teaching and learning using Twitter and blogs. International Journal of Educational Technology in Higher Education, 14(1), 3. https://doi.org/10.1186/s41239-017-0041-6

Cohen, L., Manion, L., \& Morrison, K. (2011). Research methods in education (7th ed.). New York, NY: Routledge.

Consoli, D. (2013). The implementation of a university Web 2.0 model. In M. Patrut \& B. Patrut (Eds.), Social media in higher education: Teaching in Web 2.0 (pp. 1-23). Hershey, PA: IGI Global.

Cooke, S. (2015). Social teaching: Student perspectives on the inclusion of social media in higher education. Education and Information Technologies, 22(1), 255-269. https://doi.org/10.1007/s10639015-9444-y

Cuesta, M., Eklund, M., Rydin, I., \& Witt, A.-K. (2016). Using Facebook as a co-learning community in higher education. Learning, Media and Technology, 41(1), 55-72. https://doi.org/10.1080/17439884.2015.1064952

Dede, C. (2016). Social media and challenges to traditional models of education. In C. Greenhow, J. Sonnevend, \& C. Agur (Eds.), Education and social media: Toward a digital future (pp. 95-112). Cambridge: MIT Press.

Deepak, A. C., Wisner, B. L., \& Benton, A. D. (2016). Intersections between technology, engaged learning, and social capital in social work education. Social Work Education, 35(3), 310-322. https://doi.org/10.1080/02615479.2016.1154661

Deng, L., \& Tavares, N. J. (2015). Exploring university students' use of technologies beyond the formal learning context: A tale of two online platforms. Australasian Journal of Educational Technology, 31(3), 313-327. https://doi.org/10.14742/ajet.1505

Dillon, P., Wang, R., \& Tearle, P. (2007). Cultural disconnection in virtual education. Pedagogy, Culture \& Society, 15(2), 153-174. https://doi.org/10.1080/14681360701403565

Doyle, C., Sammon, D., \& Neville, K. (2015). Building an evaluation framework for social media-enabled collaborative learning environments (SMECLEs). Journal of Decision Systems, 24(3), 298-317. https://doi.org/10.1080/12460125.2015.1054694

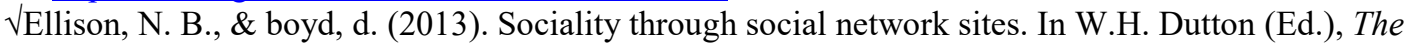
Oxford handbook of Internet studies (pp. 151-172). Oxford, United Kingdom: Oxford University Press. 
Erichsen, E. A., \& Bolliger, D. U. (2011). Towards understanding international graduate student isolation in traditional and online environments. Educational Technology, Research and Development, 59(3), 309-326. https://doi.org/10.1007/s11423-010-9161-6

Flanigan, A. E., \& Babchuk, W. A. (2015). Social media as academic quicksand: A phenomenological study of student experiences in and out of the classroom. Learning and Individual Differences, 44, 4045. https://doi.org/10.1016/j.lindif.2015.11.003

Forbush, E., \& Foucault-Welles, B. (2016). Social media use and adaptation among Chinese students beginning to study in the United States. International Journal of Intercultural Relations, 50, 1-12. https://doi.org/10.1016/j.ijintrel.2015.10.007

Gettman, H. J., \& Cortijo, V. (2015). “Leave me and my Facebook alone!” Understanding college students' relationship with Facebook and its use for academic purposes. International Journal for the Scholarship of Teaching and Learning, 9(1), art. 8. https://doi.org/10.20429/ijsotl.2015.090108

Gomes, C. P., Berry, M. P., Alzougool, B. P., \& Chang, S. P. (2014). Home away from home: International students and their identity-based social networks in Australia. Journal of International Students, 4(1), 2-15. Retrieved from https://jistudents.files.wordpress.com/2013/02/1-home-away-home.pdf

Greenhow, C., \& Lewin, C. (2016). Social media and education: reconceptualizing the boundaries of formal and informal learning. Learning, Media and Technology, 41(1), 6-30. https://doi.org/10.1080/17439884.2015.1064954

Grieve, R., Indian, M., Witteveen, K., Tolan, G. Anne, \& Marrington, J. (2013). Face-to-face or Facebook: Can social connectedness be derived online? Computers in Human Behavior, 29(3), 604-609. https://doi.org/10.1016/j.chb.2012.11.017

Habib, L., Johannesen, M., \& Leikny, Ø. (2014). Experiences and challenges of international students in technology-rich learning environments. Journal of Educational Technology \& Society, 17(2), 196-206. Retrieved from http://www.ifets.info/journals/17 2/16.pdf

Hargittai, E. (2007). Whose space? Differences among users and non-users of social network sites. Journal of Computer-Mediated Communication, 13(1), 276-297. https://doi.org/10.1111/j.10836101.2007.00396.x

Hendrickson, B., Rosen, D., \& Aune, R. K. (2011). An analysis of friendship networks, social connectedness, homesickness, and satisfaction levels of international students. International Journal of Intercultural Relations, 35(3), 281-295. https://doi.org/10.1016/j.ijintrel.2010.08.001

Higher Education Statistics Agency. (2017). Higher education student enrolments and qualifications obtained at higher education providers in the United Kingdom 2015/16. Retrieved from https://www.hesa.ac.uk/news/12-01-2017/sfr242-student-enrolments-and-qualifications

Institute of International Education. (2017). Open doors report on international educational exchange. Retrieved from http://www.iie.org/opendoors

Jackling, B., Natoli, R., Siddique, S., \& Sciulli, N. (2015). Student attitudes to blogs: A case study of reflective and collaborative learning. Assessment and Evaluation in Higher Education, 40(4), 542-556. https://doi.org/10.1080/02602938.2014.931926

Joosten, T. (2012). Social media for educators: Strategies and best practices (1st ed.). Hoboken, NJ: Wiley.

Kaplan, A., \& Haenlein, M. (2010). Users of the world, unite! The challenges and opportunities of social media. Business Horizons, 53(1), 59-68. https://doi.org/10.1016/j.bushor.2009.09.003

Kear, K., Woodthorpe, J., Robertson, S., \& Hutchison, M. (2010). From forums to wikis: Perspectives on tools for collaboration. The Internet and Higher Education, 13(4), 218-225. https://doi.org/10.1016/j.iheduc.2010.05.004

Kimmerle, J., Moskaliuk, J., Oeberst, A., \& Cress, U. (2015). Learning and collective knowledge construction with social media: A process-oriented perspective. Educational Psychologist, 50(2), 120137. https://doi.org/10.1080/00461520.2015.1036273

Lankshear, C., \& Knobel, M. (2011). New literacies : Everyday practices and social learning (3rd ed.). Maidenhead, United Kingdom: McGraw-Hill Education.

Laru, J., Näykki, P., \& Järvelä, S. (2012). Supporting small-group learning using multiple Web 2.0 tools: A case study in the higher education context. The Internet and Higher Education, 15(1), 29-38. https://doi.org/10.1016/j.iheduc.2011.08.004

Ledbetter, A. M. (2016). Friendship and social media. In M. Hojjat \& A. Moyer (Eds.), The psychology of friendship (pp. 93-108). New York, NY: Oxford University Press.

Lee, K., \& Ranta, L. (2014). Facebook: facilitating social access and language acquisition for international students? TESL Canada Journal, 31(2), 22-50. Retrieved from http://teslcanadajournal.ca/index.php/tesl/article/view/1175/995 
Li, X., \& Chen, W. (2014). Facebook or Renren? A comparative study of social networking site use and social capital among Chinese international students in the United States. Computers in Human Behavior, 35(0), 116-123. https://doi.org/10.1016/j.chb.2014.02.012

Lin, J.-H., Peng, W., Kim, M., Kim, S. Y., \& LaRose, R. (2012). Social networking and adjustments among international students. New Media \& Society, 14(3), 421-440. https://doi.org/10.1177/1461444811418627

Liu, X., Liu, S., Lee, S.-h., \& Magjuka, R. J. (2010). Cultural differences in online learning: International student perceptions. Journal of Educational Technology \& Society, 13(3), 177-188. Retrieved from http://www.ifets.info/journals/13 3/16.pdf

Manca, S., \& Ranieri, M. (2016a). Facebook and the others: Potentials and obstacles of social media for teaching in higher education. Computers \& Education, 95, 216-230. https://doi.org/10.1016/j.compedu.2016.01.012

Manca, S., \& Ranieri, M. (2016b). "Yes for sharing, no for teaching!": Social media in academic practices. The Internet and Higher Education, 29, 63-74. https://doi.org/10.1016/j.iheduc.2015.12.004

Manca, S., \& Ranieri, M. (2017). Implications of social network sites for teaching and learning: Where we are and where we want to go. Education and Information Technologies, 22(2), 605-622. https://doi.org/10.1007/s10639-015-9429-X

Marginson, S. (2009). Sojourning students and creative cosmopolitans. In M. A. Peters, S. Marginson, \& P. Murphy (Eds.), Creativity adn the global knowledge economy (pp. 217-256). New York, NY: Peter Lang.

Marwick, A. E., \& boyd, d. (2011). I tweet honestly, I tweet passionately: Twitter users, context collapse, and the imagined audience. New Media \& Society, 13(1), 114-133. https://doi.org/10.1177/1461444810365313

McCarthy, J. (2013). Learning in Facebook: First year tertiary student reflections from 2008 to 2011. Australasian Journal of Educational Technology, 29(3), 337-356. https://doi.org/10.14742/ajet.373

Mikal, J. P., Yang, J., \& Lewis, A. (2015). Surfing USA: How Internet use prior to and during study abroad affects Chinese students' stress, integration, and cultural learning while in the United States. Journal of Studies in International Education, 19(3), 203-224. https://doi.org/10.1177/1028315314536990

Minocha, S. (2009). Role of social software tools in education: A literature review. Education \& Training, 51(5/6), 353-369. https://doi.org/10.1108/00400910910987174

Moskaliuk, J., Kimmerle, J., \& Cress, U. (2012). Collaborative knowledge building with wikis: The impact of redundancy and polarity. Computers \& Education, 58(4), 1049-1057. https://doi.org/10.1016/j.compedu.2011.11.024

$\mathrm{Ng}$, W. (2015). New digital technology in education: Conceptualizing professional learning for educators. Cham, Switzerland: Springer.

Osgerby, J., \& Rush, D. (2015). An exploratory case study examining undergraduate accounting students' perceptions of using Twitter as a learning support tool. The International Journal of Management Education, 13(3), 337-348. https://doi.org/10.1016/j.ijme.2015.10.002

Owens, M., \& Nussbaum, E. M. (2017). Twitter vs. Facebook: Using social media to promote collaborative argumentation in an online classroom. Journal of Interactive Learning Research, 28(3), 249-267. Retrieved from https://www.learntechlib.org/primary/p/174165/

Park, N., Song, H., \& Lee, K. M. (2014). Social networking sites and other media use, acculturation stress, and psychological well-being among East Asian college students in the United States. Computers in Human Behavior, 36, 138-146. https://doi.org/10.1016/j.chb.2014.03.037

Piotrowskj, C. (2015). Scholarly research on educational adaptation of social media: is there evidence of publication bias? College Student Journal, 49(3), 447-451. Retrieved from https://www.ingentaconnect.com/contentone/prin/csj/2015/00000049/00000003/art00013

Pomerantz, J., Hank, C., \& Sugimoto, C. R. (2015). The state of social media policies in higher education. PLoS ONE, 10(5), 1-17. https://doi.org/10.1371/journal.pone.0127485

Poore, M. (2013). Using social media in the classroom : A best practice guide. London, United Kingdom: Sage.

Raynes-Goldie, K., \& Lloyd, C. (2014). Unfriending Facebook? Challenges from an educator's perspective. In M. Kent \& T. Leaver (Eds.), An education in Facebook?: Higher education and the world's largest social network (pp. 153-161). New York, NY: Taylor \& Francis.

Rui, J. R., \& Wang, H. (2015). Social network sites and international students' cross-cultural adaptation. Computers in Human Behavior, 49, 400-411. https://doi.org/10.1016/j.chb.2015.03.041 
Selwyn, N. (2016). Digital downsides: Exploring university students' negative engagements with digital technology. Teaching in Higher Education, 21(8), 1006-1021. https://doi.org/10.1080/13562517.2016.1213229

Selwyn, N., \& Stirling, E. (2016). Social media and education ... now the dust has settled. Learning, Media and Technology, 41(1), 1-5. https://doi.org/10.1080/17439884.2015.1115769

Shao, Y., \& Crook, C. (2015). The potential of a mobile group blog to support cultural learning among overseas students. Journal of Studies in International Education, 19(5), 399-422. https://doi.org/10.1177/1028315315574101

Sleeman, J., Lang, C., \& Lemon, N. (2016). Social media challenges and affordances for international students: Bridges, boundaries, and hybrid spaces. Journal of Studies in International Education, 20(5), 391-415. https://doi.org/10.1177/1028315316662975

Sleigh, M. J., Smith, A. W., \& Laboe, J. (2013). Professors' Facebook content affects students' perceptions and expectations. CyberPsychology, Behavior \& Social Networking, 16(7), 489-496. https://doi.org/10.1089/cyber.2012.0561

Tess, P. A. (2013). The role of social media in higher education classes (real and virtual): A literature review. Computers in Human Behavior, 29(5), A60-A68. https://doi.org/10.1016/j.chb.2012.12.032

Thompson, L., \& Ku, H. Y. (2005). Chinese graduate students' experiences and attitudes toward online learning. Educational Media International, 42(1), 33-47. https://doi.org/10.1080/09523980500116878

Tian, X. (2015). Network domains in social networking sites: expectations, meanings, and social capital. Information, Communication \& Society, 19(2), 188-202. https://doi.org/10.1080/1369118X.2015.1050051

Tinto, V. (1997). Classrooms as communities: Exploring the educational character of student persistence. The Journal of Higher Education, 68(6), 599-623. https://doi.org/10.2307/2959965

Veletsianos, G., \& Kimmons, R. (2013). Scholars and faculty members' lived experiences in online social networks. The Internet and Higher Education, 16, 43-50. https://doi.org/10.1016/j.iheduc.2012.01.004

Veletsianos, G., Kimmons, R., \& French, K. D. (2013). Instructor experiences with a social networking site in a higher education setting: expectations, frustrations, appropriation, and compartmentalization. Educational Technology Research and Development, 61(2), 255-278. https://doi.org/10.1007/s11423012-9284-Z

Wang, C. M., \& Reeves, T. C. (2007). Synchronous online learning experiences: The perspectives of international students from Taiwan. Educational Media International, 44(4), 339-356. https://doi.org/10.1080/09523980701680821

Wang, P.-Y., \& Yang, H.-C. (2012). Using collaborative filtering to support college students' use of online forum for English learning. Computers \& Education, 59(2), 628-637. https://doi.org/10.1016/j.compedu.2012.02.007

Zarkov, D., \& Davis, K. (2018). Ambiguities and dilemmas around \#MeToo: \#ForHow Long and \#WhereTo? European Journal of Women's Studies, 25(1), 3-9. https://doi.org/10.1177/1350506817749436

Zhang, Z., \& Kenny, R. (2010). Learning in an online distance education course: Experiences of three international students. International Review of Research in Open and Distance Learning, 11(1), 17-36. Retrieved from http://www.irrodl.org/index.php/irrodl/article/view/775/1501

Zhao, C.-M., \& Kuh, G. (2004). Adding value: Learning communities and student engagement. Research in Higher Education, 45(2), 115-138. https://doi.org/10.1023/B:RIHE.0000015692.88534.de

Zhao, N., \& McDougall, D. (2008). Cultural Influences on Chinese Students' Asynchronous Online Learning in a Canadian University. Journal of Distance Education, 22(2), 59-79. Retrieved from https://www.learntechlib.org/p/102726/

Corresponding author: Jade Sleeman, j.sleeman@latrobe.edu.au

Copyright: Articles published in the Australasian Journal of Educational Technology (AJET) are available under Creative Commons Attribution Non-Commercial No Derivatives Licence (CC BY-NC-ND 4.0). Authors retain copyright in their work and grant AJET right of first publication under CC BY-NC-ND 4.0.

Please cite as: Sleeman, J., Lang, C., \& Dakich, E. (2020). Social media, learning and connections for international students: The disconnect between what students use and the tools learning management systems offer. Australasian Journal of Educational Technology, 36(4), 44-56.

https://doi.org/10.14742/ajet.4384 